\title{
Dualistic reproductive behavior in the protogynous wrasse Thalassoma bifasciatum and some observations on its day-night changeover*
}

\author{
R. REINBOTH \\ Institut für Allgemeine Zoologie, Universität Mainz; \\ Mainz, Federal Republic of Germany
}

KURZFASSUNG: Dualistisches Fortpflanzungsverhalten bei dem protogynen Lippfisch Thalassoma bifasciatum und einige Beobachtungen über dessen Tag-Nacht-Wechsel. Der protogyne Blaukopf-Lippfisch Thalassoma bifasciatum laicht in den Korallenriffen des westlichen Atlantiks auf zwei verschiedene Weisen. Das typische „Blaukopf“-Männchen mit seinem besonderen Farbkleid laicht paarweise, während die Männchen mit Schlichtfärbung (ihre Färbung gleicht der der Weibchen) Gruppenlaichen betreiben. Beobachtungen an markierten Individuen im Korallenriff zeigten, daß̉ Sekundärmännchen, die durch Geschlechtsumwandlung aus Weibchen entstehen, ebenso erfolgreich laichen wie Primärmännchen mit dem "Blaukopf“-Prachtkleid. Beide Laichweisen ähneln sich darin, daß die laichenden Fische schnell zur Oberfläche des Wassers hinschwimmen, die Körper der Tiere sich für Bruchteile einer Sekunde berühren, dabei die Geschlechtsprodukte entlassen werden und die Partner sich danach schnell voneinander trennen und nach unten fortschwimmen. Ungefähr 1000-2000 Eier werden bei einem einzigen Laichakt abgegeben. Innerhalb kurzer Zeit können viele Paar- und Gruppenlaichakte stattfinden. Laichaktive Prachtmännchen verhalten sich während der täglichen Laichzeit in den Mittagsstunden territorial. Sie können über Wochen hinweg ihre dominante Stellung in der Population behaupten. T. bifasciatum ist das ganze Jahr hindurch fortplanzungsfähig. Zur Nachtzeit sucht T. bifasciatum Verstedkplätze im Riff auf, welche Territorialcbarakter haben. Der Ubergang zur Ruhephase ist mit der Zeit des Sonnenuntergangs, der Wiederbeginn der Tagesaktivität mit dem Sonnenaufgang eng korreliert.

\section{INTRODUCTION}

The bluehead wrasse Thalassoma bifasciatum is the most abundant representative of the family Labridae in the coral reefs of the tropical Western Atlantic Ocean. In a paper on the spawning behavior of parrot fishes, RANDALI \& RANDALL (1963) mentioned for the first time that in T. bifasciatum two different types of spawning may occur. These observations were confirmed later by FEDDERN (1965). It is the merit of RANDALL \& RANDALl (1963) to have discovered for the first time two different types of spawning behavior in a teleost species and to correlate this phenomenon with permanent color changes in the male sex.

* Supported by the Deutsche Forschungsgemeinschaft. 
Dichromatism of the male sex is a common feature in parrot fishes as well as in wrasses and has caused much confusion in the taxonomic literature (e.g. ScHultz 1958 , Winn \& Bardach 1957, 1960, Randall 1963, Rosenblatt \& Hobson 1969, ReINBoth 1962, Randall \& Böhlke 1965). The term "dichromatism" is somewhat ambiguous in its use in current literature. On the one hand, it serves to designate the occurrence of two different color patterns in a single species in the sense of sexual dimorphism. On the other hand, it implies - besides the difference in color between both sexes - marked differences in the coloration of male specimens. Where males of two different color types in a single species are known ("male dichromatism"), one color type (plain phase) is the same as that shown by the females, whereas the second (bright phase) is typical exclusively for males.

There exist many reports on parrotfishes and wrasses in which males with femalelike color type are considered to be "juvenile" and immature, whereas the typical male pattern is assigned to adult and sexually mature specimens. RANDALL (1963) has shown that such an interpretation is not necessarily correct for certain species, but he does not exclude that it may be valid for others. However, in my experience, which is based on histological and, partly, on experimental work on at least 7 wrasses from the Mediterranean Sea, and the Atlantic and Pacific Oceans, the distinction of dichromatic males as being juvenile or immature is untenable, since even the "juvenile" males may be fully mature (provided they have reached a certain size) and cannot be distinguished from supposedly adult ones with regard to the physiological conditions of their gonads.

The discovery of protogynous sex-inversion among wrasses and parrotfishes (REINBoth 1957, 1962, 1967, 1968, 1970, and unpublished results) adds to the complexity of "male dichromatism" in teleosts. Males of a single species may differ from each other not only in their color dress but also with regard to their origin. The stock of males in a given protogynous species may consist of primary males (they develop to males from the very beginning) and secondary males which originate by sexinversion from females. Furthermore, the relation between the developmental history of the male sex and male color types may differ in different species (REINBoth 1967). Whereas in Coris julis the bright color pattern of males develops when females transform into males (secondary males), in Thalassoma bifasciatum bright and plain (= female-like) color patterns have nothing to do with sex-inversion. Therefore, in Coris julis the plain color dress is carried by females and primary males, the fully developed bright color by secondary males, and an intermediate color pattern by transforming specimens.

In Thalassoma bifasciatum, however, the plain color pattern is found among females, primary males, secondary males, and individuals undergoing sex-inversion, whereas the bright color pattern and the intermediate coloration is restricted to males, both primary and secondary. Thus, in $T$. bifasciatum, as in most other protogynous wrasses known to us so far, the development of the bright color pattern of males apparently depends upon age and size. A description of the color patterns, although without knowledge of the peculiarities of sex-inversion, has been provided by LoNGLex \& Hildebrand (1941).

In the dichromatic parrotfish Sparisoma rubripinne, RANDALL \& RANDALI (1963) 
observed that the males which are colored like females spawn in groups, whereas the larger males with the bright color pattern spawn individually in pairs with single females. In accidental observations, the same authors have seen group spawning by Thalassoma bifasciatum. It was performed by fishes with identical color pattern (plain phase). On only two occasions has pair spawning by bright bluehead males with plainly colored females been recorded. Since we have come to know the complicated sexual organization in T. bifasciatum, a more detailed study on the species' sexual behavior seems desirable.

\section{MATERIAL AND METHODS}

The observations have been made in the shallow fringing reefs of the Northern coast of St. John/US Virgin Islands within the boundaries of the National Park (July-August, 1965, July-September, 1966, September, 1969, July-August, 1970). Further data have been collected at the Southern coast of Puerto Rico near Mayaguez (July, 1965) and in the reefs near Bimini/Bahamas (March, 1969). Except for the studies at Bimini, the observations have been carried out in collaboration with two to four persons. Depending on the various requirements for our work, we sometimes focused our interest on the continuous observation of a single or a few individuals through a whole day. We simply used a snorkel for watching the animals' activities at a water depth of 1-2 $\mathrm{m}$ or even less.

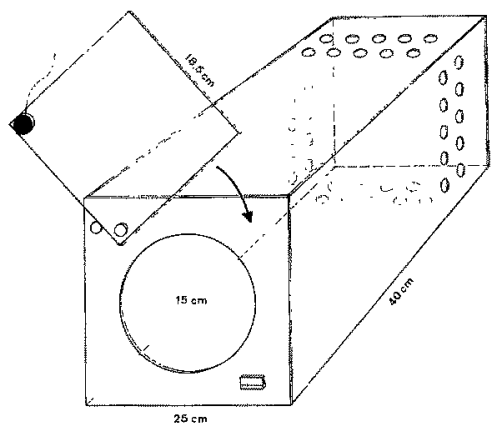

Fig. 1: Schematic drawing of the trap used to catch Thalassoma bifasciatum. Material: stiff plastic of about $3-4 \mathrm{~mm}$ thickness

In certain areas, mainly in Cinnamon and Leinster Bays (St. John, Virgin Islands) (cf. the chart provided by KumpF \& Randall [1961]) we tagged most of the larger specimens individually, using a slight modification of the technique described earlier (Rernboth 1954). Instead of Plexiglas we used round platelets of stiff plastic ( $\varnothing$ about 3-4 mm). Figures painted with white lac could be recognized easily. Fishes were lured with crushed sea urchins (Diadema) into a trap made from Plexiglas (Fig. 1).

For tagging and other experimental procedures (e.g. hormone injection) the fishes were slightly anesthetized with urethane and kept in a bucket until recovery; 
then they were released into their habitat. Underwater recordings were made on a slate with an appropriate pencil.

For photographic documentation we employed a Nikonos and an electronic Hasselblad camera with underwater housing. Motion pictures (24 and 64 frames/sec) were made with a Bolex camera, $16 \mathrm{~mm}$, in a Bolex underwater housing. The movie camera was mounted on a specially designed underwater tripod with adjustable feet and an upper, horizontally rotating turntable which could be locked by a screw. In addition, the platform of the turntable could be bent down- and upward to an angle of about $40^{\circ}$ and $140^{\circ}$, respectively, between the plane of the platform and the central axis of the tripod.

\section{RESULTS}

\section{Pair spawning}

Individual pair spawning by larger bright-colored Thalassoma bifasciatum males with smaller females is the most conspicuous behavior pattern that can be seen in any reef inhabited by the bluehead.

\section{The spawning act}

Following observation of many hundreds (or even more) pair spawnings, a typical spawning sequence may be described as follows (Figs. 2,3). The female approaches the male from below. The male, being or becoming aware of her, gets more and more excited and intensifies his circling above her, clockwise and counterclockwise, with his body bent and his tail quivering rapidly. The female looks upward toward the male and approaches slowly while the male is rising in a spiral movement towards the surface. The circling movement ends abruptly. Both fish, the female below the male, swim straight forward and upward for a certain distance (at the most about $1 \mathrm{~m}$ ). They may touch each other momentarily, but usually the female is a little ahead of the male. The male, however, has its head above or at least close to the female's caudal end. Finally, the male catches up with the female which regularly starts to move in a more vertical direction. This is the beginning of the climax during which both fish clasp each other in such a way that their genital openings come very close to each other for hardly more than $1 / 6$ to $1 / 10$ of a second. After this, both fish separate and swim rapidly downwards in different directions - the female usually more quickly and far ahead of the male. A tiny cloud of sex products (sperm) marks the place where the fish released their germ cells.

This sequence of events is substantiated by many photographs and by careful analysis of slow-motion pictures, frame by frame. The pictures indicate that, in the final stage of the spawning act, the female turns more or less upside down, probably in order to bring her swollen and sparkling white belly as close to the male's genital opening as possible. At the same time, a sharp bending of the male's body promotes the contact between the animals. More exact details could be revealed only by a further increase in the speed of the film. 
Repeatedly, we have collected eggs immediately after spawning using a small plankton net $(\varnothing$ of the opening $30 \mathrm{~cm}$, depth $50 \mathrm{~cm}$ ). The net, fastened to a stick, was moved as rapidly as possible back and forth and up and down in the region where the fish had spawned. The results of our catches are summarized in Table 1.

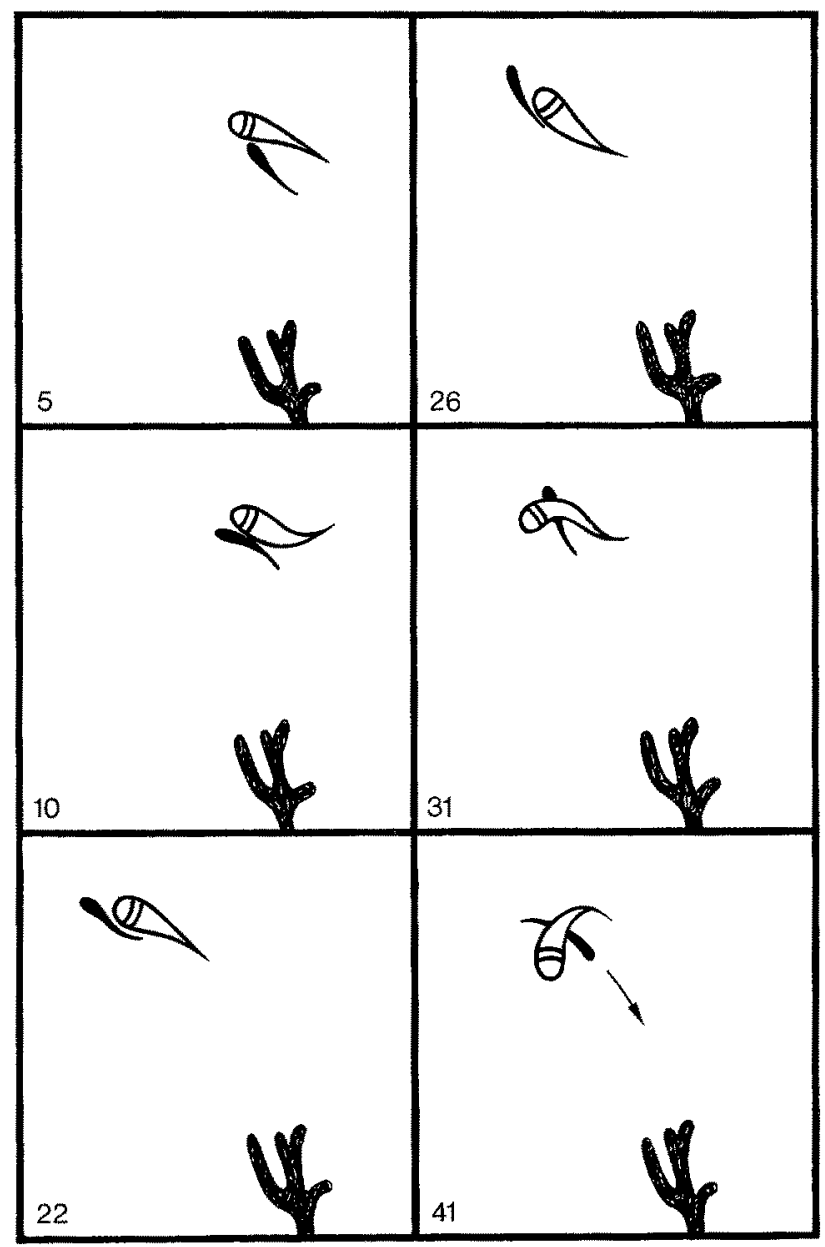

Fig. 2: Thalassoma bifasciatum. Semischematic drawing of various stages of pair spawning. Numbers correspond to single frames of one spawning sequence taken at 64 frames/sec. Release of sex products at frame 31

Control catches obtained from other places, or 1 minute after spawning, yielded no eggs or at the most considerably fewer. The transparent planktonic eggs have a tiny oil globule and are extremely small (cf. FEDDERN 1965). Most eggs remained transparent and floated at the water surface in our collecting vials even after 1 hour (which I consider an indication of their viability). The lack of laboratory facilities made it impossible to observe embryonic development. Eggs were not eaten by predators. 
Table 1

Thalassoma bifasciatum. Number of eggs caught with a plankton net after single spawning acts

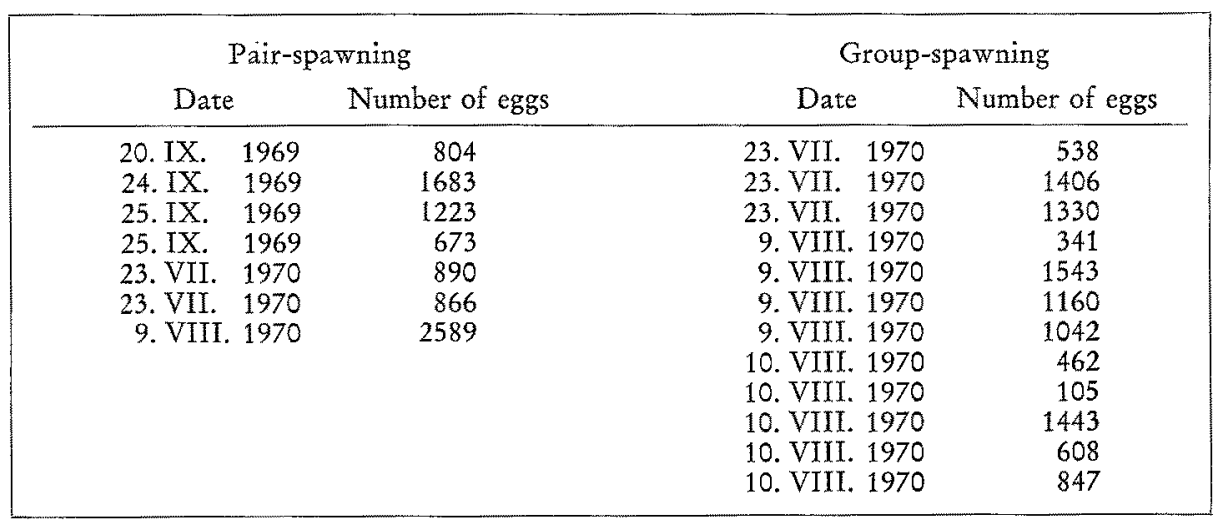

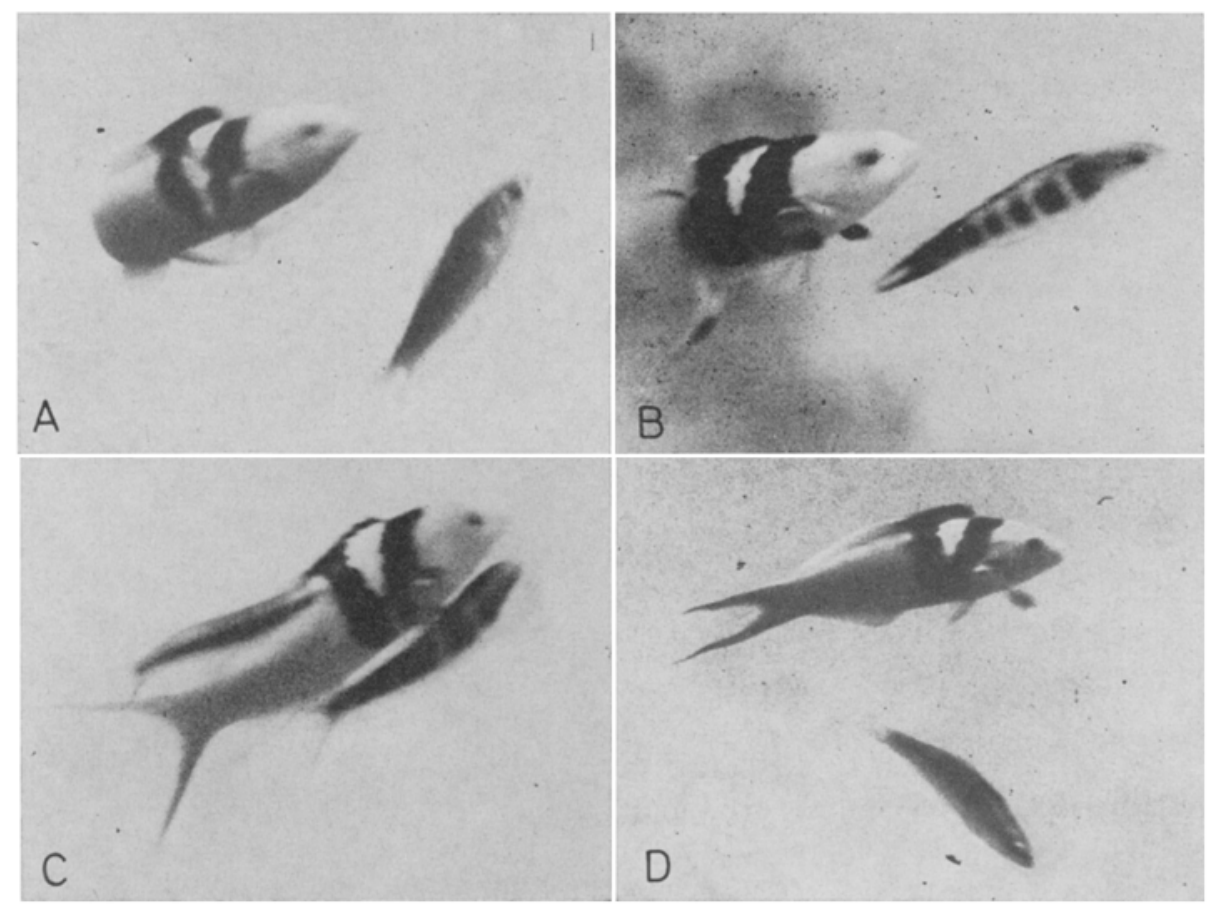

Fig. 3: Thalassoma bifasciatum. Selected snapshots from pair spawnings. Sequence corresponds to that of Figure 2. C shows an unusual "trio"-formation

A single male may spawn many times per day, sometimes at very short intervals. In one of the motion pictures, one male spawned with 2 different females within less than 3 seconds. The second female swam upward toward the male, whilst the first one moved downward. On the way down, the male met his second partner in a 
perfectly elegant move, running up with her immediately. Sometimes a second female may join the running move of a couple (cf. Fig. $3 \mathrm{C}$ ). I am unable to state whether in such cases the fish actually spawn as a trio. The number of spawning acts seems to depend mainly upon the number of females ready to spawn. In many cases, even during a 2-hour period of continuous observation, active males succeeded to spawn only once. On the other hand, a single male may spawn more than 20 times a day. A maximum count of at least 15 spawnings by a single male within only 35 minutes cannot be considered as unusual.

Pair spawning occurs only during the period between about 11:30 a.m. and 2:30 p.m., with maximum activity between noon and 1:00 p.m. Bad weather conditions (heavy overcast or rainfall) did not interfere with spawning.

\section{Prespawning behavior of the bright males}

There is no distinct courtship behavior of bright males towards females. Nevertheless, some behavior pattern of the bright male can be recognized which precedes spawning activities and which I like to refer to as "prespawning behavior". A male swimming actively across the reef may bend his body towards a female which he meets on his way, erecting his dorsal fin at the same time. But the next moment he continues his way without paying further attention to the potential partner he has passed. Only rarely may a male pass the same female two or three times in a slalomlike fashion when the female itself is moving along some distance in the reef.

During the daily period of spawning activity, the bright male goes frequently to one particular place in the reef where most of his spawning acts are performed. These places are always located directly at, or very close to, the outer edge of the reef towards the open sea. A place may be marked by some prominent coral, rock, a gorgonian, or a sea fan. In this region, the male spends much of his time. It is doubtful whether the term "territory" might be justified for such places. The males do not effectively defend any boundaries and a clear preference for those sites cannot be seen except during the limited period of spawning activities. The term "spawning area" provides a more appropriate description. Its size is difficult to define. In a horizontal plane it may cover between about 1-4 $\mathrm{m}^{2}$. We know several spawning areas which remained exactly the same from 1965 to 1970 . In the spawning area the bright male shows some particular activities which, in our opinion, focus the female's attention on that spot or on the male himself.

The most striking behavioral pattern of the male is a movement that we call "looping": the male makes a run, swims more or less vertically upward (over a distance of about $60-120 \mathrm{~cm}$ ) with very distinct wriggling movements of the posterior part of his body, makes a quick and sharp turn and swims back in the direction of the starting point. The downward movement is a little more rapid than the upward phase. Whole series of 8,10 or more loopings may directly follow each other. A single looping takes less than 1 second. The loopings intensify when a female approaches or can be seen not too far away. Even when we were unable to detect any females, loopings were performed. Hence we interpret this male behavior as a signal to the females, 
indicating the site where the male is ready to spawn. We often saw mature females coming to the spawning place and waiting there while the male was absent. In such cases it could happen that, after the male's return, they spawned quickly without any preliminaries. One or two other spawning rushes might follow immediately provided that several females had lined up to await their male partner.

Similar behavior has been observed in several species of the genus Chromis and has been called "Signalsprung" (signal jump) by ABEL (1961) (cf. MYrberg et al. 1967, AlbRECHT 1969, SWERDLOFF 1970).

\section{Owners of a spawning area}

In a given reef area, the number of sexually active bright males always exceeds the total number of bright males present. This situation is particularly conspicuous in reefs which are isolated from each other, e.g. by larger areas with sandy bottom (some fringing reefs in Cinnamon Bay offer excellent examples of that type).

From our observations in such places we learned that the total number of bright males may be up to 3 or even 4 times larger than the number of active ones. The sexually active males are owners of at least one spawning area from which they frequently depart for across-the-reef-excursions lasting up to several minutes. Nonactive males can also be found at well-defined locations of the reef during the daily reproductive period, but they are generally much less active; they do not roam about in the same way, and they never spawn, although there are always females present.

Due to the variety of our studies in several reefs at St. John and sometimes because of bad weather conditions (hurricanes) we have not been able to keep a complete daily record of the sexual activity of a larger number of bright males tagged individually. Nevertheless, we know that a single specimen is able to spawn for weeks at the same place. For example, male no. 7, which we observed (each time for several minutes) on 30 days between July 27 and September 26, spawned above the same rock on 11 days. Male no. 3, observed between July 27 and August 23, spawned on at least 11 days out of 20. Following hurricane "Faith" (1966), which forced us to interrupt our work in that particular reef from August 25 to September 7, male no. 3 was inactive and seemed to be sick. On September 8 he was seen in the reef for the last time.

Although the possession of one spawning area is the general rule, one male may accupy 2 or - more rarely - 3 spawning areas, swimming busily back and forth between those places. However, one spawning area is always distinctly preferred. The largest distance measured between different spawning areas of one male was $17 \mathrm{~m}$. (The total length of the bright male rarely exceeds $13 \mathrm{~cm}$.)

The possession of a spawning area by one particular male usually excludes any other male from spawning at the same place. Only when the proprietor is far away might another male succeed occasionally to perform a quick spawning act and recedes immediately afterwards. Similarly, spawning areas could be taken over temporarily by inactive males when we removed its proprietor for a short time from the reef in order to be tagged. In summary, it can be stated that a few males are sexually domi- 
nant and force the others of the same area to remain passive. The correctness of this interpretation is supported by experiment.

An almost completely isolated reef was inhabited by 4 bright males, among which only the largest $(A)$ had been spawning actively for 10 days above the most prominent elkhorn coral (Acropora palmata) of the entire reef in the middle of its outer edge. We removed that particular fish (A) on August 9 in the afternoon. The next day, one of the other males (B), which we had never seen to be active sexually, took over the spawning area after he had started sexual activities near the place which had been until then his "residential area". The next day the upstart (B) kept his dominant position with the privilege of spawning. But the following day (August 12) another of the "inferior" males (C) had occupied the prominent spawning area and remained the only spawning male for another 11 days. On August 24 we caught this particular male (C) at 10:40 a.m. Continuing our observations at 12:00 p.m. we found male D spawning above the elkhorn coral (the former area of $\mathrm{A}$ ). But then, for about 1 hour, $B$ and $D$ were chasing each other ferociously across the reef, frequently changing - without perceptible cause - their roles as pursuer and pursued. In the meantime, a smaller male with intermediate color pattern took advantage of this situation and spawned several times above the elkhorn coral. Finally, the chase ended abruptly, male D took over the prominent spawning area, B went to its former home range and spawned there several times. After the release of male $C$ back to the reef in the afternoon of the same day, this individual swam straight to the spawning area. $\mathrm{D}$, who was close by, was briefly threatened twice with erected fins by C. D performed marked "bow"-swimming with depressed fins. Such behavior seems to be a gesture of inferiority which we have seen frequently. It may also be a symptom of general discomfort which invariably could be observed when we brought fish from a certain area to another reef not familiar to them.

The foregoing report which is but one example from our observations and experiments indicates that:

(1) A hierarchy exists among bright males which prevents a number of them from becoming sexually active. But every male is able to spawn. Under particular circumstances even intermediate males which have not yet developed fully the bright color pattern may take the role of typical large-sized bluehead males.

(2) The ranking order may be upset by disturbances. Fighting among the males, which may include chasing and sometimes even biting with mouth pulling and swirling around each other is very rare. Normally, occasional and very short thrusts by the dominant male against a potential rival seem to be sufficient to maintain the ranking order. It is not unusual for an inactive male to come directly to the spawning area of another male without being disturbed. Although the bluehead male has a typical placard-like coloration, a corresponding aggressiveness as postulated by LORENZ (1963) was not observed.

In reefs in which we spent a considerable amount of time, and in which the fishes probably became accustomed to us, we were able to elicit ferocious attadks by presenting a mirror to dominant males. Inferior males responded with "bow"-swimming only. In reefs that we visited less frequently similar experiments with a mirror yielded no definite results. 
After terminating our experiments we killed some of the males that had been tagged individually and prepared their gonads for histological examination. From the results of this work it became obvious that sexual dominance has nothing to do with the ontogeny of bluehead males; dominant as well as inferior individuals could be either primary or secondary males.

\section{Group spawning}

Normally, group spawning (aggregate spawning in the terminology of RANDALL \& RANDALL [1963]) is effected by fish (males or females) which exhibit the female-like color pattern (plain phase). When bright bluehead males are present they evidently disturb the groups by aggressiveness, although sometimes they try to

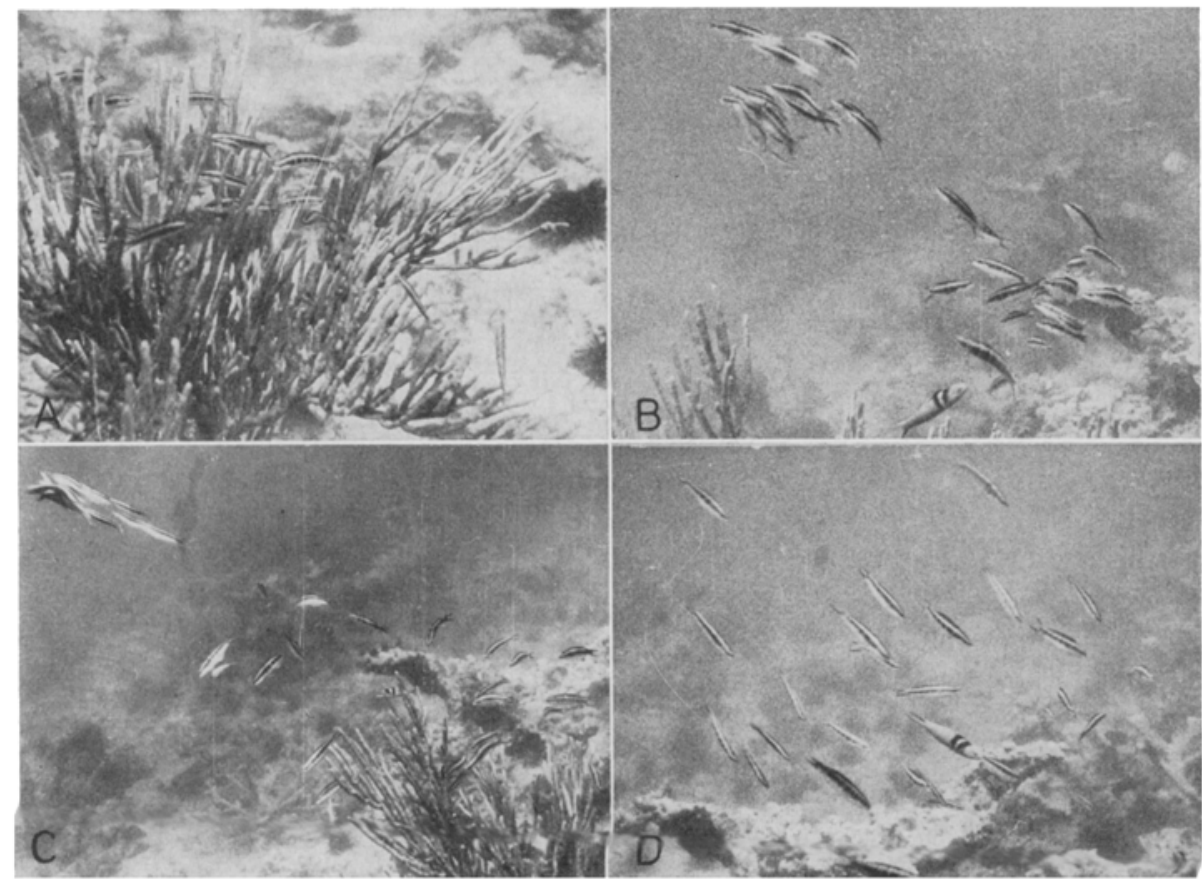

Fig. 4: Selected snapshots from group spawnings. Sequence corresponds to that of Figure 5

join a spawning group. The description given by RANDALL \& RANDall (1963, p. 55) is fully confirmed: "The fish usually concentrate their activity over prominent rocks or heads of coral... Within this aggregation smaller groups of about 5 to 10 or more fish began to swim more rapidly in one direction and then another. As with parrot fishes, there was a sudden upward or diagonally upward movement which resulted in the fish being a maximum of about 2 feet above the rest of the group. A small cloud of white could often be seen, indicating release of sperm." 
Similar to the situation in pair spawning, the spawning places are located near the outer edge of the reef towards the open sea. In reefs in which we observed group spawning frequently, it always occurred at the same place, which could be identical with the spawning area of a single bright male (REINBOTh 1972a). Whereas pair spawning can be seen in every reef inhabited by Thalassoma bifasciatum, even small ones, group spawning accurs only in large reefs with large numbers of $T$. $b i$ fasciatum.

The beginning of a spawning act is marked by spatial concentration of fish milling around, and by the onset of parallel movements. The size of the groups is highly variable. Whereas RANDALL \& RANDALx (1963) have seen groups with 80 and more members, we observed groups comprising hardly more than 50 individuals. In contrast to the observations by RANDALI \& RANDALI (1963), the length of fish forming a group often considerably exceeded $60 \mathrm{~mm}$. Analysis of motion pictures from group spawning activities revealed that already in the initial stage of the upward rush of the group (which had been concentrating before) some fish move a little more slowly up- and forward. In this way the fish "cloud" loses more and more of its original density. At the same time, however, a few fish on top (about 5 to 10 individuals) rush closely together forming a "ball" and then separate immediately after releasing their sexual products. They swim down very rapidly and join other descending members of the group (Figs. 4, 5).

The entire sequence, from the start of the upward rush of the entire group until the release of eggs and sperm, takes much less than a second. The spawning act proper, that is the formation of the "spawning ball" and its subsequent dissolution occurs within less than $1 / 10$ of a second. Several spawning acts may follow in quick succession and may be a matter of 1 to 3 seconds only.

I am unable to state whether in such cases always different fish participate in the spawning act. Since we repeatedly observed that the number of spawning acts (sometimes more than 50/day at the same place) exceeded the number of individuals comprising the entire group, at least some females must spawn several times per day. It seems unreasonable to assume that one female only participates in each group spawning and that the rather constant size of a group is maintained by a departure of the spawned females and their replacement by other females from the reef.

The sex ratio in the group is unknown. Non-selective catches of Thalassoma bifasciatum invariably revealed a large preponderance of females.

The number of eggs that could be collected from group spawnings are given in Table 1.

The time of day at which group spawning occurs is about the same at which we have seen pair spawning. In Hawksnest Bay (St. John, Virgin Islands), however, where we did most of our observations in 1970, group spawning was seen several times as late as $3: 15$ p.m. Intense group spawning activities lasted from about $1 / 2$ hour up to 2 hours/day. RANDALL \& RANDALl (1963) suggested a correlation between group spawning and the lunar cycle. The data of these authors have been communicated by FEDDERN (1965). Our observations do not agree with such findings. Between July 23 and August 10,1970, observations were carried out on a total of 15 days, but on only 


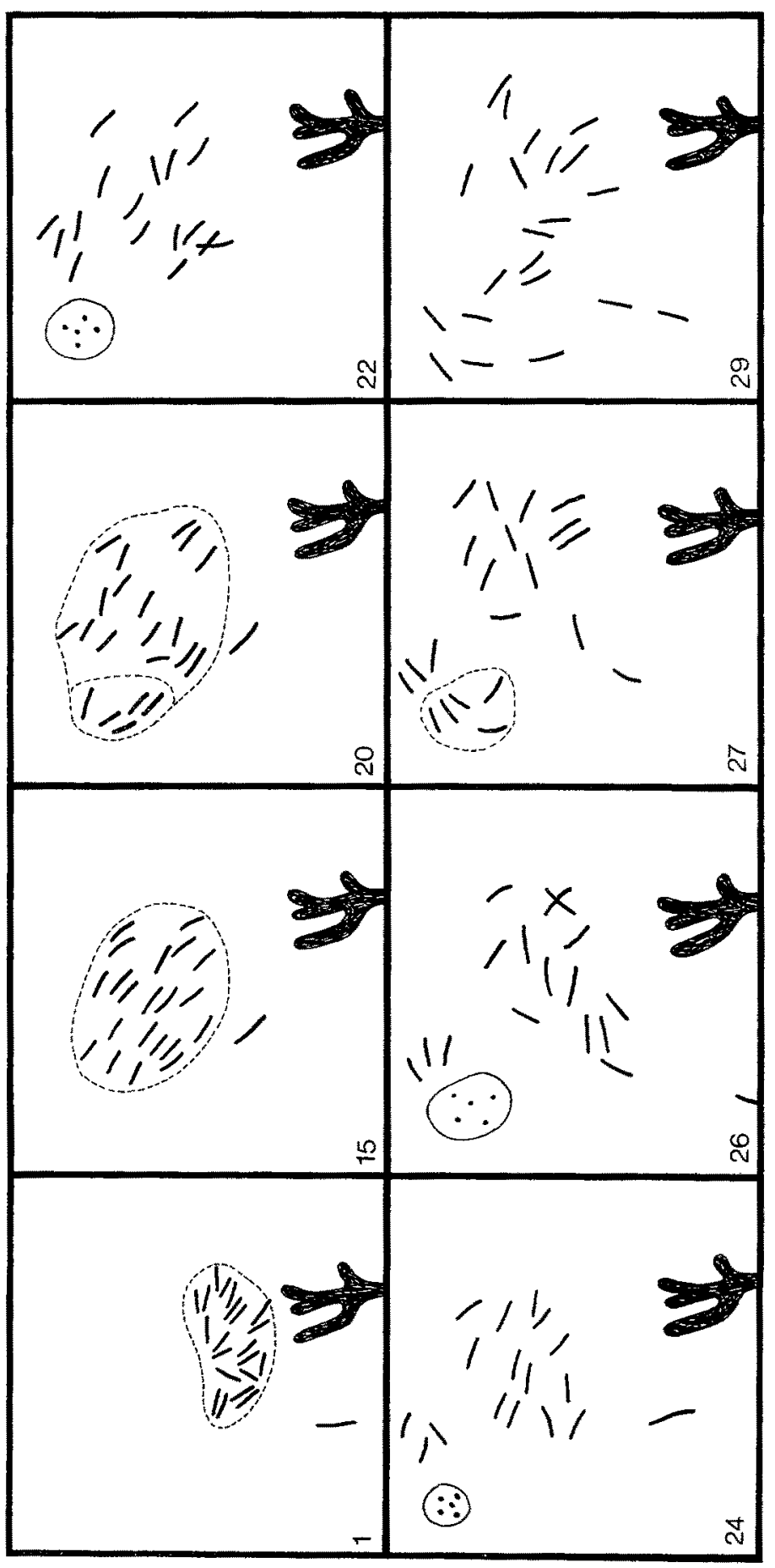

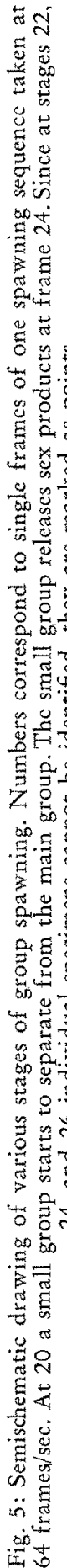


2 days (July 31 and August 5) did we fail to see group spawning. In former years we deliberately chose days in the middle between full moon - new moon - full moon for visits to Haulover Bay (St. John) and regularly we were able to see group spawning, in contrast to the assumption made by RANDALI \& RANDAII (1963).

\section{Day-night changeover}

Wrasses are well known for their marked changes in daily activity pattern. Many dig themselves into sandy bottoms during night-time (ReINBoth 1971a, b). Thalassoma bifasciatum seek shelter in small crevices and holes of reef formations or find rest between algae around the time of sunset. At sunrise they come out of the same hiding places they entered the evening before. From regular observations of tagged specimens, we learned that each individual has its own "sleeping"-place to which it normally returns every day. One individual kept its place throughout the entire observation period (July 27-August 21). In other specimens we observed changes of the hiding place after several days. Whether this is due to disturbances by the observer or interference by other fish is not known. We frequently observed damselfishes attadking $T$. bifasciatum when these tried to enter their holes within the territory of a pomacentrid. It must be assumed that each $T$. bifasciatum knows several potential hiding places in the reef since it finds a "new" shelter without preceding search.

The nocturnal hiding place of the bright males may be several meters away from their spawning area. It is mostly situated in the inner part of the reef area and sometimes lies only a few centimeters below the surface of the water at low tide. The exactness with which the fish enter or leave their hiding places at a particular moment,

Table 2

Thalassoma bifasciatum. Data on the day-night changeover

\begin{tabular}{|c|c|c|c|c|c|}
\hline Specimens & $\begin{array}{l}\text { Observation } \\
\text { period }\end{array}$ & $\begin{array}{l}\text { Time of } \\
\text { sunset } \\
\text { (EDT) }\end{array}$ & $\begin{array}{l}\text { Number } \\
\text { of events } \\
\text { observed }\end{array}$ & $\begin{array}{l}\text { Average } \\
\text { deviatio } \\
\text { of sun }\end{array}$ & $\begin{array}{l}\text { Maximal } \\
\text { com time } \\
\text { (min) }\end{array}$ \\
\hline Bright male III & July $27-$ & 18.56 & 15 & 147 & -13 \\
\hline \multirow[t]{2}{*}{ Bright male IV } & July 27 - & $\begin{array}{l}18.42 \\
18.56\end{array}$ & 13 & $T 4.7$ & $\begin{array}{l}14 \\
-13\end{array}$ \\
\hline & Aug. 21 & 18.42 & 21 & +2.1 & +12 \\
\hline Plain colored fish & July $28-$ & $\begin{array}{l}18.56 \\
18.48\end{array}$ & 13 & $+4 ?$ & $\mp 1$ \\
\hline \multirow[t]{2}{*}{ Bright male 4} & Aug. 2 - & $\begin{array}{l}18.40 \\
18.54\end{array}$ & 15 & & \\
\hline & Sept. 12 & 18.24 & 10 & +8.3 & +12 \\
\hline \multirow[t]{2}{*}{ Bright male 44} & $\begin{array}{l}\text { Sept. } 12- \\
\text { Sept. } 26\end{array}$ & $\begin{array}{l}18.24 \\
18.13\end{array}$ & 5 & +7.6 & +10 \\
\hline & & $\begin{array}{l}\text { Time of } \\
\text { sunrise } \\
\text { (EDT) }\end{array}$ & & \multicolumn{2}{|c|}{$\begin{array}{l}\text { Average Maximal } \\
\text { deviation from time } \\
\text { of suntise (min) }\end{array}$} \\
\hline Bright male 4 & $\begin{array}{l}\text { Sept. } 18- \\
\text { Sept. } 27\end{array}$ & $\begin{array}{l}6.07 \\
6.09\end{array}$ & 7 & +2.7 & +9 \\
\hline Bright male 44 & $\begin{array}{l}\text { Sept. } 18- \\
\text { Sept. } 27\end{array}$ & $\begin{array}{l}6.07 \\
6.09\end{array}$ & 7 & -2 & -4 \\
\hline
\end{tabular}


correlated with the time of sunset and sunrise, is remarkable (Table 2). In only $10 \%$ of more than 100 single observations was the deviation from the time of sunset and sunrise more than \pm 10 minutes. In Table 2 the time of sunset and sunrise is given in Eastern Daylight Saving Time (EDT) for $\lambda \mathrm{EDT}=60^{\circ} \mathrm{W}$, and was calculated for $\varphi=18^{\circ} 30^{\prime} \mathrm{N}$. Since the latitude of our observation reef was at $\lambda=64^{\circ} 45^{\prime} \mathrm{W}$ (time difference corresponding to $\lambda=4^{\circ} 45^{\prime}: 19$ minutes) one must conclude that Thalassoma bifasciatum seeks shelter shortly before sunset and comes out again before sunrise. We have not been able to find any significant correlation between weather conditions (rainfall, clear skys, overcast) and the time of the changeover. It must be pointed out that the reef was open to the West; it was blocked off against sunshine in the early morning by mountains in the East.

About 1 hour before sunset the activity of the bright males slowed down considerably. Frequently, the fish became nearly stationary at particular places way off from their hiding places. They could be located regularly at these spots day after day. Only occasionally did they leave for short excursions into the surrounding reef, mostly chasing other individuals. Usually, they reached their hiding places by a rapid and straight swim, sometimes with a short stop at another place in between.

It is remarkable that bright males mostly had 1 or 2 smaller specimens associated with them as "satellites". These satellites were either plain colored males and females or smaller intermediate males. Although bright males chased the satellites frequently these mostly stayed very close to the bright male's stationary place. After a bright male had entered its hole, the satellite went there too and inspected it from a short distance. Sometimes the bright male came out again and ferociously attacked the intruding fish before it quickly went back to its shelter (cf. ReINBOTH 1972 b). So far we have foregone experimental interventions in order to avoid disturbances in our data collecting; nevertheless, it has become obvious that strong competition exists for hiding places which are claimed as individual property.

\section{DISCUSSION}

At about the same time when Randall \& Randall (1963) mentioned for the first time the occurrence in the open sea of two types of spawning behavior in Thalassoma bifasciatum, ZuMPE (1963) presented a brief report on the behavior of $T$. bifasciatum from observations on 4 individuals kept in an aquarium containing $1.8 \mathrm{~m}^{3}$ of water. ZUMPE discovered activities described as pair spawning in this paper. In spite of the limited size of the tank, which was much smaller than the space which the animals normally use in their natural habitat, ZUMPE made some statements which agree fairly well with our data. This holds true for the selection by the male of a particular area which then becomes the spawning area, the active role of the female which approaches the male, the very rapid upward rush of both fish towards the water surface, and their quick return to the bottom.

In the aquarium, however, both sexual partners did not really get together. The female released her eggs whilst the male remained above and behind (!) her; there are 
some other details which do not agree with our in-situ observations. Knowing the wide range of movements of sexually active Thalassoma bifasciatum, such discrepancies are hardly surprising. Due to the lack or faultiness of information on the behavior of the fish in situ, ZUMPE (1963) arrived at several conclusions and speculations which are quite untenable. This should be a serious warning against the use and judgement of observations under artificial conditions when nothing is known about the animal's life in nature. On the other hand, the complex situation in the open sea with some inherent difficulties for practical work, may exclude experiments which can be relatively easily carried out in an aquarium.

FIsHELson (1970) has done a remarkable study on the protogynous Anthias squamipinnis. According to his report, the presence of 1-2 males in a group of 10-20 females prevents spontaneous sex-inversion of females. If he removed the males, however, one of the females became a male within 2 weeks. Repeating the removal of the male, he finally had no female left. Obviously such observations cannot be made in the sea, where hundreds or even thousands of individuals of the same species live together in stationary groups. Our observations on Thalassoma bifasciatum in the reef preclude statements on whether similar processes might occur in this protogynous species under natural conditions. Even if this were the case, one could not record it since color change and sex-inversion are not related to each other in $T$. bifasciatum. The question arises, however, whether the change from the plain to the bright color pattern in primary and secondary males might be regulated in some way by the presence (or relative abundance) of bright males in a certain area. $\mathrm{A}$ remark by ZuMPE (1963) might well point in this direction. Her fish measured $4 \mathrm{~cm}$ when she started her observations and she reports that one of her fish started to change its color one week after it became aggressive. Unfortunately, she did not specify the time at which this happened. Nor does she present figures on length when "several months" later one of the 3 other fish (all of them were recorded as having spawned as females) became a brightly colored male. It cannot be excluded that ZuMPE's first bright male was considerably smaller than all the hundreds we have seen and caught in the sea.

The physiological mechanism which causes the change from plain to brightcolor patterns in the males is unknown. So far, we have not been able to detect any histological difference in the male gonads, apart from the architecture of testes from primary and secondary males (REINBOTH 1970). On the other hand, a single injection of testosterone into plain males of any size and even into females - these experiments have been done with fish living in the reef - elicits development of the bright color pattern.

In one of the reefs in which we removed or reduced the number of bright males, we gained the impression that the change from plain males to bright males was enhanced and we had the opportunity to observe males with intermediate color pattern engaged in pair spawning. But our data are insufficient for definite statements. I can only say that, in males with a distinct intermediate color dress, pair spawning is the only way of reproduction although such activities are more the exception than the rule. Usually they are chased more vigorously than other individuals by the bright males (cf. REINBOTH 1972b). 
This raises the fundamental question: what is the biological meaning of male dichromatism and how is it correlated with the dualistic mode of spawning?

As mentioned previously, group spawning does not occur at all places where Thalassoma bifasciatum can be found. We got the impression that group spawning requires a certain minimum population density, present in most well-developed and extensive reef formations in the Western Atlantic Ocean. In smaller reef areas, however, that are more or less isolated, pair spawning prevails or is the only mode of reproduction. Even in the smallest patch of coral formation inhabited by T.bifasciatum at least one bright male can be seen to be active. It is tempting to speculate that pair spawning is the most efficient way of reproduction in cases where equal physiological readiness may hardly be attained simultaneously by a number of individuals. Pair spawning lessens the necessity for exact timing, a prerequisite of successful group spawning. Since the male is able to spawn during long periods, pair spawning ensures the production of offspring when only one female is ready to shed her sexual products; timing is necessary by two partners only. The bright color pattern of the male, in combination with its very conspicuous behavior (loopings, circling above prominent coral), serves as optical clue reducing mutual communication to a time minimum in the highly temporary process of pair formation.

There is no indication of seasonal dependency of pair spawning and group spawning. FEDDERN (1965) claims that spawning of Thalassoma bifasciatum in the Virgin Islands takes place in every month except September. Since we, however, have obtained many of our data throughout the month of September in these islands, it must be assumed that, at this latitude, $T$. bifasciatum reproduces through the whole year. Certain observations from the Northern Bahamas, however, do not exclude the possibility that in this region the early months of the year are a period of sexual quiescence in that species.

\section{SUMMARY}

1. Thalassoma bifasciatum is a protogynous wrasse with (partial) sexual dimorphism and male dichromatism. Sex-inversion takes place without affecting the color pattern.

2. Males with female-like color dress indulge in group spawning; males with the bright color pattern perform pair spawning.

3. Among the brightly colored males exists a well-established hierarchy. Dominant males only have a particular spawning area in which they spawn daily at a certain time around noon. The spawning area is optically marked by conspicuous behavior of the bright male. Courtship activities towards individual partners are rather superficial.

4. The female has the leading role in pair spawning. In the extremely short spawning act a female may release, simultaneously, more than 2000 eggs.

5. Group spawning occurs in well-populated reef areas only. The basic pattern of group spawning has many similarities to pair spawning.

6. Day-night changeover of T. bifasciatum is closely correlated to the time of sunset and sunrise. 
7. The possible biological significance of the dualistic spawning behavior is discussed, and advantages as well as drawbacks of studies in the sea and in aquaria are considered.

Acknowledgments. The author is much indebted to R. KuHn, Dr. N. Simon, R. Simon, and Dr. Fisher-Mamblona for scientific cooperation. Mr. and Mrs. J. Woodside, former commissioners of Cinnamon Camp provided generous help of all kinds. The Superintendents of the National Park and their staff lent us their support. The advice of Mr. Noble Samuer, ranger of the National Park, is highly appreciated. Mr. R. MATTHEwson, Director of the Lerner Marine Laboratory at Bimini and his staff were equally helpful. The "Institut für den wissenschaftlichen Film" at Göttingen provided material for the motion pictures. Funds for the expeditions have generously been provided by the "Deutsche Forschungsgemeinschaft", Bad Godesberg (FRG), "The Lalor Foundation", Wilmington/Delaware (USA), the Vereinigung "Freunde der Universität Mainz" (FRG), and several industrial companies, to all of which the author is much indebted.

\section{LITERATURE CITED}

ABeL, E. F., 1961. Freiwasserstudien über das Fortpflanzungsverhalten des Möndhfisches Chromis chromis LINNÉ, einem Vertreter der Pomacentriden im Mittelmeer. Z. Tierpsychol. 18, 441-449.

Albrecht, H., 1969. Behaviour of four species of Atlantic damselfish from Columbia, South America (Abudefduf saxatilis, A. taurus, Chromis multilineata, C. cyanea; Pisces Pomacentridae). Z. Tierpsychol. 26, 662-676.

FedDeRn, H. A., 1965. The spawning, growth, and general behavior of the bluehead wrasse, Thalassoma bifasciatum (Pisces: Labridae). Bull. mar. Sci. 15, 896-941.

Fishelson, L., 1970. Protogynous sex reversal in the fish Anthias squamipinnis (Teleostei, Anthiidae) regulated by the presence or absence of a male fish. Nature, Lond. 227, 90-91.

KumpF, H. E. \& Randall, H. A., 1961. Charting the marine environments of St. John, U.S. Virgin Islands. Bull. mar. Sci. Gulf Caribb. 11, 543-551.

Longley, W. \& Hrodebrand, S. F., 1941. Systematic catalogue of the fishes of Tortugas, Florida. Pap. Tortugas Lab. 34, 1-331.

LoRENz, K., 1963. Das sogenannte Böse. Borotha-Schoeler, Wien, 391 pp.

Myrberg, A. A., Brahr, B. D. \& Emery, A. R., 1967. Field observations on reproduction of the damselfish, Chromis multilineata (Pomacentridae), with additional notes on general behavior. Copeia 1967, 819-827.

RANDall, J. E., 1963. Notes on the systematics of parrotfishes (Scaridae), with emphasis on sexual dichromatism. Copeia 1963, 225-237.

- \& BöHLke, J. E., 1965. Review of the Atlantic labrid fishes of the genus Halichoeres. Proc. Acad. nat. Sci. Philad. 117, 235-259.

- \& Randall, H. A., 1963. The spawning and early development of the Atlantic parrot fish, Sparisoma rubripinne, with notes on other scarid and labrid fishes. Zoologica, N.Y. 48, $49-60$.

Rernboth, R., 1954. Eine Methode zur Markierung von Aqquarienfischen. Zool. Anz. 153, 190-194.

- 1957. Sur la sexualité du Téléostéen Coris julis (L.). C. r. hebd. Séanc. Acad. Sci., Paris 245, 1662-1665.

- 1962. Morphologische und funktionelle Zweigeschlechtlichkeit bei marinen Teleostiern (Serranidae, Sparidae, Centracanthidae, Labridae). Zool. Jb. (Allg. Zool. Physiol. Tiere) 69, $405-480$.

- 1967. Biandric teleost species. Gen. comp. Endocr. 2 (Abstr.), 146.

- 1968. Protogynie bei Papageifischen (Scaridae). Z. Naturf. (B) 23, 852-855. 
- 1970. Intersexuality in fishes. In: Hormones and the environment. Mem. Soc. Endocr. 18, 516-543.

- 1971a. Coris formosa (Labridae) - Eingraben. Encycl. Cinemat., Göttingen, Nr E 1597 (Film).

- 1971b. Coris julis (Labridae) - Eingraben. Encycl. Cinemat., Göttingen, Nr E 1598 (Film).

- 1972a. Thalassoma bifasciatum (Labridae) - Paar- und Gruppenlaichen in Korallenriff. Encycl. Cinemat., Göttingen, $\mathrm{Nr}$ E 1776 (Film).

- 1972b. Thalassoma bifasciatum (Labridae) - Aufsuchen des nächtlichen Ruheplatzes. Encycl. Cinemat., Göttingen, Nr E 1777 (Film).

Rosenblatt, R. H. \& Hobson, E. S., 1969. Parrotfishes (Scaridae) of the Eastern Pacific, with a general rearrangement of the Scarinae. Copeia 1969, 434-453.

Schultz, L. P., 1958. Review of the parrotfishes family Scaridae. Bull. U.S. natn. Mus. 214.

SWERdLoff, S. N., 1970. Behavioural observations on Eniwetok damselfishes (Pomacentridae: Chromis) with special reference to the spawning of Chromis caeruleus. Copeia 1970, 371-374.

WINN, H. E. \& BARDACH, J. E., 1957. Behavior, sexual dichromatism, and species of parrot fishes. Science, N.Y. 125, 885-886.

- - 1960. Some aspects of comparative biology of parrotfishes at Bermuda. Zoologica, N.Y. 45, 29-34.

Zumpe, D., 1963. Uber das Ablaichen von Thalassoma bifasciatum. Dt. Aquar.-Terrar.-Z. 16, $86-88$.

Author's address: Prof. Dr. R. Rernsoth

Johannes-Gutenberg-Universität

Institut für Allgemeine Zoologie

6500 Mainz

Saarstraße 21

Federal Republic of Germany 